\title{
OSTENTATIO GENITALIUM, CZYLI SEKSUALNOŚĆ CHRYSTUSA JAKO DOWÓD WCIELENIA
}

\section{LEO STEINBERG}

\section{SEKSUALNOŚĆ CHRYSTUSA.}

\section{ZAPOMNIANY TEMAT SZTUKI RENESANSOWEJ}

Kamil Kopania

Uniwersytet Warszawski

W jednym z konserwatywnych kwartalników katolickich ukazał się artykuł poświęcony szeroko propagowanej akcji „Cała Polska czyta dzieciom” (Moryń 2012: 226-238). Autorka artykułu cytuje m.in. taki oto fragment z książki przeznaczonej dla młodego czytelnika, a zatytułowanej Wielka ksiega siusiaków: „W piętnastym i szesnastym wieku włoscy artyści przeważnie malowali Jezusa leżącego w ramionach matki i ciągnącego się za siusiaka. Na wielu płótnach Matka Boska dotyka krocza swojego syna”. Autorka jest oburzona twierdzeniem, które traktuje jako wierutną bzdurę i atak na wartości: „Cóż, ja takich prac nie znam, ale to pewnie wina Watykanu, który w piwnicach pochował owe dzieła bądź zdążył je spalić!” (tamże: 231). Nie zadaje sobie pytania, skąd autorzy Wielkiej ksiegi siusiakón zaczerpnęli informację o takich motywach malarskich, lecz sarkastycznie sugeruje, że po prostu piszą nieprawdę. Tymczasem to, że „takich” prac nie zna, nie jest bynajmniej ani wina Watykanu, ani też autorów wspomnianej publikacji, tylko brakiem jej wiedzy na temat sztuki religijnej dawnych wieków, w wielu aspektach poważnie odbiegającej od stereotypowych wyobrażeń o niej. Nie mamy tu na myśli jedynie występowania mniej lub bardziej zadziwiających współczesnego widza motywów, które z różnych powodów wydają się niestosowne i które przez wielu moga być zbyte jako humorystyczne, marginalne, po prostu nieistotne. Odrzucając a priori istnienie dzieł religijnych podkreślających cielesność i płciowość Chrystusa, autorka wspomnianego 
tekstu - może i nieświadomie, nawet w dobrej wierze, ale jednak - odrzuca jeden z kluczowych wątków debaty teologicznej, jakim jest Wcielenie Chrystusa. Nauka o wcieleniu, rozważania oscylujące wokół prawdy wiary głoszącej, że Syn Boży przyjął ludzkie ciało oraz ludzką naturę, przybierały na przestrzeni wieków różne formy. W XV i XVI stuleciu znajdowały ciekawe odzwierciedlenie w sztuce religijnej, zarówno zamawianej przez świeckich na ich prywatne potrzeby, jak i powstającej z inicjatywy i na potrzeby samego Kościoła. Płótna, na których „Matka Boska dotyka krocza swojego syna", maja głęboki sens teologiczny: ukazywanie, a nawet swoiste podkreślanie genitaliów Zbawiciela prowadzić miało bowiem do unaocznienia podstawowej prawdy wiary, wedle której Chrystus, zstępując na ziemię, stał się prawdziwym człowiekiem. Ludzie tamtych czasów bardzo poważnie podchodzili do prawdy wiary, że Jezus to Bóg, który stał się prawdziwym i rzeczywistym człowiekiem, a więc jako człowiek miał te wszelkie ludzkie cechy, które składają się na nasze człowieczeństwo. I stawiali sobie pytanie, czy ludzka seksualność współtworzy naszą ludzką naturę, bo jeśli tak, to również Jezus musiał jako Człowiek być świadom swojej seksualności. Teologiczna antropologia ostrożnie poruszała ten temat, choć i pomijać go nie mogła; sztuki plastyczne mogły być pod tym względem o wiele bardziej odważne, gdyż ich istota jest przekaz zmysłowy. Można zaryzykować twierdzenie, że naturalna i zdroworozsądkowa postawa wobec ciała i ludzkiej seksualności znalazła wyraz właśnie w sztuce, nie zaś w teologii pozostającej pod wielkim wpływem neoplatońskiego i gnostyckiego rozumienia materii jako źródła zła ${ }^{1}$. Jedną z najbardziej znaczących prac poświęconych tej kwestii jest książka Leo Steinberga The Sexuality of Christ in Renaissance Art and in Modern Oblivion z 1984 roku, której polski przekład, Seksualność Chrystusa. Zapomniany temat sz̨tuki renesansowej, właśnie się ukazał.

Leo Steinberg (1920-2011), postać o ciekawej i skomplikowanej historii rodzinnej, syn emigranta, rosyjskiego Żyda Izaaka Nachmana Steinberga, był amerykańskim krytykiem i historykiem sztuki, przez lata związanym z City University of New York i University of Pennsylvania. W 1983 roku opublikował w czasopiśmie „October” artykuł The Sexuality of Christ in Renaissance Art and in Modern Oblivion, jeden z bardziej wpływowych i szeroko dyskutowanych esejów naukowych lat 80 . XX wieku, w znaczący sposób ukierunkowujący badania z zakresu historii sztuki. Wspomniana książka

\footnotetext{
${ }^{1}$ Obszerne informacje bibliograficzne na temat skomplikowanego i pełnego sprzeczności stosunku teologii do problematyki cielesności znaleźć można w: Salisbury 1990, Bullough, Brundage 1996. O chrześcijańskich postawach wobec ludzkiej seksualności w okresie 1500-1750 pisze WiesnerHanks 2000. Bogaty materiał źródłowy zawiera Rogers 2001. O teologicznym lęku przed seksualnością traktuje Elliott 1999.
} 
Leo Steinberga bazuje nie na wyjściowym, potężnych rozmiarów artykule (szybko zresztą, bo w 1984 roku, wydanym w wersji książkowej), lecz publikacji z 1997 roku, drugiej edycji książkowej (Chicago University Press). Wydanie z 1997 roku różni się od pierwszego. Zawarto w nim bowiem nie tylko artykuł z pisma „October”, ale i zespół tekstów powstałych w późniejszym czasie, zawierających nowe przykłady dzieł o interesującej Steinberga ikonografii, polemiki z recenzentami bądź uszczegółowienia wyrażonych wcześniej tez. W efekcie czytając Seksualność Chrystusa, obcujemy z książką dość nietypowo skomponowaną, na swój sposób eklektyczną, będącą zbiorem tekstów pomyślanych nie tyle jako jednorodna pod względem formy i stylu publikacja dotycząca zawartego w tytule tematu, ile raczej zestawienie wyjściowego, potężnego rozmiarami artykułu z innymi tekstami powstałymi po jego opublikowaniu, stanowiącymi swoistą dokumentację sporów oraz kontrowersji, które wywołał.

Książka składa się z trzech głównych części. Pierwsza partia głównego tekstu to potężnych rozmiarów erudycyjny, stanowiący wprowadzenie do tematu rozdział Seksualnośc Chrystusa. Zapomniany temat sztuki renesansowej. Steinberg ze swadą nakreśla w nim przedmiot prowadzonych przez siebie badań, zwracając uwagę czytelnika na szereg zabiegów stosowanych przez artystów głównie II połowy XV i I połowy XVI stulecia, działających na terenie Italii oraz w krajach na północ od Alp. Koncentruje się przede wszystkim na kompozycji dzieł malarskich i graficznych, w przypadku których uwaga patrzacego kierowana jest na - zazwyczaj odkryte, dobrze widoczne - genitalia małego Jezusa znajdującego się na kolanach Matki (Steinberg używa w odniesieniu do tego rodzaju dzieł terminu ostentatio genitalium). Analizując dziesiątki wyobrażeń malarskich i graficznych, autor szczegółowo omawia różne warianty kompozycji, w których postać Dzieciątka upozowana została w charakterystyczny sposób, przekonująco dowodząc, że ułożenie Jego nóżek, to, jak stoi bądź siedzi, skupia wzrok patrzącego na jego przyrodzeniu. Oprócz tego podaje przykłady dzieł, w których genitalia są wyraźnie uwidocznione, gdyż Maria kieruje w ich stronę dłoń bądź też nawet bezpośrednio ich dotyka. Steinberg analizuje też warianty, w których mamy do czynienia z przezroczystą tkaniną okalającą biodra Jezuska bądź też szata, która w dziwny sposób przykrywa większą część ciała Zbawiciela, jednak z pominięciem genitaliów. Podając przykłady scen pasyjnych, przede wszystkim Ukrzyżowania, ale też Piety, Piety Patris, Złożenia do grobu, zwraca uwagę na analogiczne sposoby podkreślania genitaliów Chrystusa, a także nowe ujęcia, w których dłonie zmarłego Zbawiciela zostały złożone na Jego łonie. Więcej, autor książki podkreśla, że w przypadku niektórych 
przedstawień (Ukrzyżowanie, Chrystus Umęczony) tkanina okalająca biodra Zbawiciela ułożona bywa w sposób wysoce nienaturalny, nielogiczny, za to wyraźnie sugerujący wzwód ukrytego pod nią członka.

Przedstawienia tego rodzaju, tworzone przez wielu wybitnych, często „podręcznikowych” artystów, takich jak Giovanni Bellini, Hans Baldung Grien, Maerten van Heemskerck, Andrea Mantegna, Michał Anioł czy Rogier van der Weyden, łączy Steinberg z chęcią uwypuklenia podstawowego zagadnienia teologicznego odnoszącego się do statusu ontologicznego Chrystusa - Wcielenia. W opinii badacza w sztuce II połowy XV i I połowy XVI stulecia wyraźnie widoczna jest chęć zaznaczenia w sposób subtelny i bezpośredni zarazem ludzkiej natury Zbawiciela, z wszystkimi bez mała jej wyznacznikami, w tym jednym z podstawowych, a więc seksualnością. Bazując na materiale wizualnym, autor książki wykazuje, że seksualność Chrystusa we wspomnianym wyżej czasie nie była tematem łatwym, w szczególności zaś prostym do zobrazowania w sztukach wizualnych, ale jednak nie była tematem pomijanym, uważanym za niewłaściwy do rozważania bądź przedstawiania. Więcej, podkreśla znaczenie motywów seksualnych, zasadzające się na przekonaniu o szczególnej wadze Wcielenia, swoistej celebracji faktu, że Chrystus miał zarówno boską, jak i ludzką naturę. Bezpośrednio ukazywana cielesność stanowić miała wyznacznik człowieczeństwa, przez biblijne skojarzenia z grzechem pierworodnym łączyć Zbawiciela z rodzajem ludzkim (oczywiście bez przypisywania Mu skażenia tymże grzechem) i podkreślać wagę Jego misji, dzięki której jednostka dostąpić może zbawienia. Zasugerowana erekcja może być z kolei traktowana jako motyw stanowiący odniesienie do żywotności, witalności, a w kontekście religijnym - zmartwychwstania. Badacz zaznacza jednocześnie, że tego rodzaju skojarzenia stanowią wyjątek w dziejach Kościoła, zarówno bowiem przed omawianym okresem, jak i po nim kwestie związane z seksualnością Chrystusa były podejmowane sporadycznie, a już na pewno nie w tak otwarty i bezpośredni sposób, czego wymownym dowodem jest sam fakt powszechnej nieświadomości istnienia analizowanych przez niego motywów. Świadczy to o odejściu Kościoła, najpewniej po Soborze Trydenckim, od rozważań skierowanych w tę stronę.

Choć drobiazgowe analizy kolejnych obrazów przekonują do twierdzeń Steinberga - nie sposób zaprzeczyć, że w przypadku wielu dzieł późnośredniowiecznych i renesansowych narzucającym się widzowi motywem są genitalia Chrystusa - to jednak wywód autora pozostawia niedosyt wynikający z braku jakichkolwiek źródeł mogących potwierdzać stawiane tezy. 
W toku rozważań sam Steinberg przyznaje zresztą, że nie dysponuje żadnymi tekstami teologicznymi z epoki, które mogłyby uprawdopodabniać jego spostrzeżenia, a te, na które się powołuje, dotyczą kwestii cielesności Chrystusa w innym kontekście, np. obrzezania jako wydarzenia związanego z pierwszym przelaniem krwi Zbawiciela, cierpieniem stanowiącym zapowiedź zbawczej męki. Zapewne z tego względu po głównej części mamy do czynienia z blokiem trzydziestu dziewięciu krótkich tekstów opatrzonych zbiorczym określeniem Ekeskursy. Uznać je można za zbiór uzupełnień dotyczących podnoszonych wcześniej zagadnień oraz dzieł. Steinberg, posiłkując się szeregiem nowych przykładów malarskich i graficznych, dodatkowo uszczegóławia wybrane kwestie, ukazuje je w szerszym kontekście, próbując znaleźć odniesienia w myśli, teologii i sztuce Kościoła, mogące świadczyć o właściwym klimacie intelektualnym oraz emocjonalnym, pozwalającym na tworzenie interesujących Steinberga dzieł (autor analizuje m.in. motyw Marii karmiącej Dzieciątko, czyni też szerokie odniesienia do zagadnień związanych z pojmowaniem ciała i cielesności we wczesnym chrześcijaństwie oraz średniowieczu).

Trzecia część książki nosi tytuł Retrospekcja i stanowi swoiste pokłosie szerokiego oddźwięku, jaki przyniosła książka Steinberga. Zostało w niej zebranych dziesięć tekstów poprzedzonych wstępem, w którym autor szczegółowo opisuje liczne, głównie nieprzychylne, często całkowicie niemerytoryczne, kpiące wypowiedzi dotyczące jego dzieła, a także jego samego. Steinberg z wyrozumiałością traktuje atakujących, wychodząc z założenia, że ich działania są wymownym przykładem wyparcia oczywistych faktów ze świadomości, odrzucania a priori dowodów wizualnych, przede wszystkim zaś - typowym przejawem tabuistycznego myślenia, wykluczającego jakąkolwiek rozsądną dyskusję. Wyraża także zadowolenie z głosów tego rodzaju, których efektem było wzmożone zainteresowanie jego publikacja, bezpośrednio przekładające się na wyniki jej sprzedaży. We wspomnianych dziesięciu podrozdziałach odpowiada na wattpliwości oraz pytania tych, którzy odnieśli się do jego tekstu w sposób merytoryczny. W toku kolejnych wywodów stara się podać nowe argumenty na rzecz wyrażonych w tekście głównym tez, w szczególności wychodząc od obszerniejszej grupy pism teologicznych i religijnych, w których podejmowane były kwestie cielesności. Posiłkuje się też licznymi nowymi przykładami dzieł malarskich, rzeźbiarskich i graficznych, w tym takimi, które potwierdzają, że na pewnym etapie dziejów pomysły późnośredniowiecznych i renesansowych artystów, starających się w wymowny sposób podkreślić ludzką naturę Jezusa, przestały być akceptowane i zrozumiałe zarówno dla wiernych, jak 
i dla kleru. Mowa tu o dziełach przemalowanych w taki sposób (np. poprzez domalowanie fragmentu tkaniny), aby ukryć wyraźnie widoczne genitalia Zbawiciela.

Steinberg nie podsumowuje swoich wywodów. Książka kończy się Epilogiem, w którym czytelnik znajdzie opowieść o spotkaniu Steinberga z pewnym Holendrem, lokalnym miłośnikiem historii i zabytków, autorem listu do niego z informacją o ambonie w miejscowości Schiedam.

W jej dekoracji pojawia się motyw Dobrego Pasterza, którego szaty w okolicach lędźwi układają się w kształt rozety. Autor listu napisał, że od dawna miał przeczucie, że taki nietypowy motyw musi być świadomie zastosowanym przez artystę środkiem wskazania na ukryte pod szata genitalia Chrystusa, ale dopiero dzięki książce Steinberga nabrał przekonania, że faktycznie o to chodzi. Dla Steinberga było to z jednej strony swoistym poświadczeniem, że motywy, o których pisze, są oczywiste, łatwe do odczytania dla wszystkich, z drugiej zaś stanowiło dowód o szerokim odbiorze jego książki, przywracającej zapomniane bądź mało znane motywy sztuki dawnej, co daje nadzieję na dokonanie rewizji potocznego jej odbioru.

Treść Epilogu wydaje się w pełni zasadna. Steinberg faktycznie wprowadził do badań nad sztuką, kulturą i umysłowością dawnych wieków temat słabo znany, niemal zapomniany. Temat ciekawy nie tylko dla specjalistów, ale i szerszego grona miłośników sztuki oraz kultury. Nie bez znaczenia jest również fakt, że Seksualność Chrystusa... dotyka problemów dla niektórych trudnych do zaakceptowania, kontrowersyjnych, a więc zarazem swoiście nośnych. Praca Steinberga odegrała dzięki temu istotną rolę w procesie kształtowania się zainteresowań historyków sztuki i kultury II połowy lat 80. oraz kolejnych dziesięcioleci. Amerykański badacz może być w znacznej mierze traktowany jako ojciec chrzestny wielu projektów badawczych skupiających się na zagadnieniach pomijanych w badaniach nad sztuką dawną. Nie sposób przypisać mu wszystkich zasług na tym polu, w analogicznym bowiem czasie „nieortodoksyjnymi” zagadnieniami zajmowała się choćby adwersarz Steineberga, z którą ten polemizuje w trzeciej części swojej książki: Caroline Walker Bynum, zasłużona badaczka kultury, autorka wielu intrygujących prac dotyczących religijności i pojmowania ciała w kulturze późnego średniowiecza². Innym ważnym

\footnotetext{
${ }^{2}$ Bynum krytykuje Steinebrga z pozycji feministycznych, kładąc silny akcent na tendencje do feminizowania Zbawiciela w myśli oraz praktyce mistycznej średniowiecza. W opinii badaczki Steinberg podchodzi do analizowanych przez siebie obrazów w sposób jednowymiarowy i tendencyjny, oparty na pojęciach związanych z tradycyjną wizją seksualności. W latach 80 . i na początku 90 . Bynum opublikowała m.in. książki: Jesus as Mother. Studies in the Spirituality of the High Middle Ages (Bynum
} 
i wpływowym badaczem, analizującym i wyjaśniającym nietypowe dla współczesnego widza motywy sztuki średniowiecznej, takie jak wyjątkowa agresja i przemoc zauważalna w scenach pasyjnych, jest James Marrow. Jego publikacje z przełomu lat 70. i 80. doprowadziły do rewizji szeroko rozpowszechnionych opinii dotyczących znacznej części sztuki średniowiecznej jako wykwitu dolorystycznej pobożności lubującego się w przemocy społeczeństwa. Marrow przekonująco wykazał, że liczne brutalne, dynamiczne sceny pasyjne warunkowane są w pierwszej kolejności typologią biblijną (Marrow 1977, 1979)³.

Jednakże to właśnie od połowy lat 80 . zauważamy znaczacy wzrost liczby prac poświęconych mniej znanym przejawom sztuki średniowiecznej, które dla wielu mogą się wydać nie tyle nawet niezrozumiałe albo dziwne, ile po prostu szokujące. W 1986 roku Anthony Weir i James Jerman podjęli temat obscenicznych wyobrażeń licznie występujących w architektonicznej dekoracji rzeźbiarskiej wielu kościołów średniowiecznej Europy (Weir, Jerman 1986) ${ }^{4}$. Postaci kobiece i męskie (a także hybrydalne ludzko-zwierzęce) w ekshibicjonistycznych pozach, bezwstydnie prezentujące genitalia bądź wypinające się w stronę patrzącego pośladkami, kopulujące pary - wszystkie te motywy, wydawałoby się całkowicie nie do zaakceptowania w kościelnych wnętrzach bądź na zewnętrznych ścianach świątyń, były szeroko rozpowszechnione i akceptowane zarówno przez świeckich, jak i duchowieństwo (zaznaczyć należy - przedstawiciele duchowieństwa ponad wszelką wątpliwość musieli wydawać zgodę na powstanie tego rodzaju wyobrażeń w obrębie świątyni). W latach 90. nietypowym motywom, przede wszystkim na kartach rękopisów iluminowanych, kilka publikacji poświęcił Michael Camille 5 . W jego pracach czytelnik znajdzie analizy humorystycznych, obscenicznych, wulgarnych bądź rubasznych scen, które odnaleźć można na marginesach psałterzy, godzinek, jak i innych ksiąg, za-

1982); Holy Feast and Holy Fast. The Religious Significance of Food to Medieval Women (Bynum 1987); Fragmentation and Redemption. Essays on Gender and the Human Body in Medieval Religion (Bynum 1991). Zob. również artykuł Bynum: Skęd taki zamet wokót ciała? Z perspektyny mediewistki (Bynum 2002).

${ }^{3}$ Warto w tym miejscu wspomnieć o dziele z terenu Polski, które z racji na swoją wyjątkową brutalność, jeśli chodzi o opis oraz wizualizację męki Chrystusa, może być postrzegane opacznie jako wykwit późnośredniowiecznego - z dzisiejszej perspektywy patrząc - prymitywnego, wulgarnego, a nawet niesmacznego doloryzmu (jako takie było zresztą opisywane przez wielu badaczy). Mowa o Rozmyślaniach dominikańskich, wyjątkowym zabytku sztuki i piśmiennictwa I połowy XVI wieku, powstałym w Krakowie. Zob.: Kopania 2004 (tam też odniesienia do innych niż Marrowa prac, których istotą jest wykazanie, że brutalne sceny pasyjne były wyrazem teologicznego myślenia, a nie odbiciem niezdrowej afektacji przemoca). Zob. też: Bale 2010, Mills 2005.

${ }^{4}$ Z nowszych prac zob.: Karkov 2001, Mellinkoff 2004.

${ }^{5}$ Patrz przede wszystkim: Camille 1992. Patrz też Camille 1998. Szeroko na temat motywów seksualnych w sztuce i kulturze religijnej późnego średniowiecza oraz ich wielorakich uwarunkowań patrz m.in.: Burgwinkle, Howie 2010, Easton 2006. 
zwyczaj służących celom liturgicznym bądź związanych z pobożnością ludzi świeckich. W latach późniejszych wątki poruszane przez Camille’a rozwijali kolejni badacze, ukazujący, jak bogaty, niejednoznaczny i ciekawy był świat średniowiecznej seksualności, wbrew obiegowym opiniom często pełnej radości i swobody (McDonald 2006, Lindquist 2012, Wolfthal 2010). Ich rozważania koncentrują się także na współistnieniu motywów seksualnych i religijnych w teologii, sztuce czy literaturze średniowiecza ${ }^{6}$.

Ruth Mellinkoff z kolei dogłębnie omówiła sztukę późnego średniowiecza pod kątem sposobów, w jaki obrazowano cierpienia Jezusa (Mellinkoff 1993). Badaczka skupiła się przede wszystkim na postaciach oprawców, którzy na kwaterach średniowiecznych nastaw ołtarzowych czy kartach rękopisów iluminowanych prezentowani byli w sposób dla współczesnego widza niedopuszczalny. Mowa tu o fizjonomii oprawców, mającej za cel ich zohydzenie i stanowiącej wymowny znak ich grzeszności. Problem jednak w tym, że deformacja twarzy czy ciała w wielu przypadkach była odbiciem różnego rodzaju schorzeń, przede wszystkim skórnych, ale także wenerycznych czy nowotworowych, potrafiących silnie wpłynąć na wygląd zewnętrzny osób na nie cierpiących. W takim przypadku znamiona choroby traktowane były jako dowód grzeszności noszących je osób. Równie istotne z punktu widzenia ikonografii pasyjnej sa gesty pojawiające się w niektórych dziełach doby późnego średniowiecza. Mowa tu o geście figi, wysuwaniu języka czy np. rozszerzaniu palcami ust z jednoczesnym wysuwaniem języka. Tego rodzaju znaki, czynione w odniesieniu do postaci Chrystusa bądź Marii, są ofensywne w charakterze i mają konotacje seksualne. Potwierdzają to zarówno liczne wzmianki w literaturze, jak i sposób ich wykorzystania w ikonografii świeckiej.

Wśród elementów mających podkreślać brutalność i wątpliwą kondycję moralną oprawców znajdziemy inne jeszcze motywy. Zadający cierpienie Chrystusowi często ukazywani byli w strojach udziwnionych pod względem kroju, wielokolorowych, kusych, obcisłych, często zniszczonych, odkrywających niektóre partie ciała oraz w zbrojach mających wyraźnie prześmiewczy charakter (np. żołnierze przedstawiani byli w słomianych hełmach) (Bayless 2007). Znaczna część tych ubiorów znajdowała odzwierciedlenie w realiach dnia codziennego - oglądający sceny pasyjne mieli odnosić je do konkretnych postaci wykonujących problematyczne pod względem moralnym zawody - ludzi rozrywki, w pierwszej kolejności

${ }^{6}$ Patrz np. ważne opracowanie zbiorowe: Marek, Preisinger, Rinnele, Kärcher 2008 (tam bogata bibliografia). 
aktorów, do których stosunek Kościoła od początku chrześcijaństwa był zdecydowanie negatywny?

Wydanie Seksualności Chrystusa..., bogato ilustrowanej, w bardzo dobrym językowo polskim tłumaczeniu, profesjonalnym, jeśli chodzi o umiejętność wykorzystania fachowej nomenklatury i oddanie różnego rodzaju niuansów terminologicznych, uznać należy za właściwą decyzję. Inspirująca praca Steinberga pozwoli wielu osobom zrewidować obiegowe, silnie zakorzenione poglądy na sztukę religijną średniowiecza oraz renesansu. Ukaże ją w nowym, może kontrowersyjnym dla wielu, ale ciekawym świetle. Szczególną i podstawową wartością pracy Steinberga jest jednak przekonujące wykazanie, że w tematach, które dla wielu moga być kontrowersyjne, a nawet moralnie niedopuszczalne, tkwi ładunek głębokiej treści odnoszącej się do fundamentalnych problemów teologicznych, w tym przypadku związanych z naturą Jezusa Chrystusa, a więc kwestią Wcielenia. Lektura omawianej książki stanowi również doskonała zachętę do dalszego pogłębiania wiedzy rewidującej utarte schematy myślowe. Wspomniane wyżej publikacje innych autorów, wiele zawdzięczających badaniom Steinberga, ukazują chrześcijańską kulturę i sztukę jako silnie zakorzenioną w codziennym życiu ludzi średniowiecza, z ich prawdziwymi emocjami i odmiennym od naszego sposobem przeżywania świata. Pozwalają zrozumieć, że umysłowość ludzi średniowiecza różni się od naszej, ale dlatego właśnie ich postawa religijna i sposoby interpretowania wielu kwestii teologicznych zdają się nam tak osobliwe.

Bibliografia:

/// Bale A. 2010. Feeling Persecuted. Christians, Jens and Images of Violence in the Middle Ages, Reaktion Books, London.

/// Bayless. M. 2007. Clothing, Exposure, and the Depiction of Sin in Passion iconography, [w:] Weaving, Veiling, and Dressing. Textiles and their Metaphors in the Late Middle Ages, red. K.M. Rudy, B. Baert, Brill, Turnhout, s. 289-305.

/// Bullough V.L., Brundage J.A., red. 1996. Handbook of Medieval Sexuality, Routledge, New York.

/// Burgwinkle B., Howie C. 2010. Sanctity and Pornography in Medieval Culture. On the Verge, Manchester University Press, Manchester.

\footnotetext{
${ }^{7} \mathrm{Na}$ temat różnego rodzaju motywów negatywnie definiujących oprawców patrz: Kopania 2012 (tam też liczne odniesienia bibliograficzne).
} 
/// Bynum C.W. 1982. Jesus as Mother. Studies in the Spirituality of the High Middle Ages, University of California Press, Berkeley, Los Angeles.

/// Bynum C.W. 1987. Holy Feast and Holy Fast. The Religious Significance of Food to Medieval Women, University of California Press, Berkeley, Los Angeles.

/// Bynum C.W. 1991. Fragmentation and Redemption. Essays on Gender and the Human Body in Medieval Religion, Zone Books, New York.

/// Bynum C.W. 2001. Skad taki zamet wokót ciata? Z perspektywy mediewistki, tłum. I. Sławińska, „Teksty Drugie”, nr 5, s. 74-96.

/// Camille M. 1992. Image on the Edge. The Margins of Medieval Art, Reaktion Books, London.

/// Camille M. 1998. The Medieval Art of Love. Objects and Subjects of Desire, Laurence King Publishing, New York.

/// Easton M. 2006. The Wound of Christ, the Mouth of Hell. Appropriations and Inversions of Female Anatomy in the Later Middle Ages, [w:] Tributes to Jonathan J. G. Alexander. The Making and Meaning of Illuminated Medieval \& Renaissance Manuscripts, Art \& Architecture, red. S. L'Engle, G.B. Guest, Harvey Miller Publishers, Turnhout, s. 395-414.

/// Elliott D. 1999. Fallen Bodies. Pollution, Sexuality, and Demonology in the Middle Ages, University of Pennsylvania Press, Philadelphia.

/// Karkov C.E. 2001. Sheela-na-gigs and Other Unruly Women. Images of Land and Gender in Medieval Ireland, [w:] From Ireland Coming. Irish Art from the Early Christian to the Late Gothic Period and Its European Context, red. C. Hourihane, Princeton University Press, Princeton, s. 313-331.

/// Kopania K. 2004. Stowo - obraz - teatr. Uwagi na temat „Rozmyślań dominikańskich”, „Biuletyn Historii Sztuki”, R. LXVI, nr 1-2, s. 7-48.

/// Kopania K. 2012. Prz̨edstawienia odrażajace w późnośredniowiecznym malarstwie z terenów dzisiejszej Polski - zarys problematyki, [w:] Ars historiae / bistoria artis. Prace ofiarowane Profesorowi Andrzejowi Wyrobiszowi, red. E. Dubas-Urwanowicz, J. Maroszek, Wydawnictwo Uniwersytetu w Białymstoku, Białystok, s. 61-72.

/// Lindquist S.C.M., red. 2012. The Meanings of Nudity in Medieval Art, Ashgate, Aldershot. 
/// Marek K., Preisinger R., Rinnele M., Kärcher K., red. 2008. Bild und Körper im Mittelalter, Wilhelm Fink Verlag, München.

/// Marrow J.H. 1977. 'Circumdederunt me canes multi'. Christ's Tormentors in Northern European Art of The Late Middle Ages and Early Renaissance, „The Art Bulletin" June, vol. LIX, nr 2, s. 167-181.

/// Marrow J.H. 1979. Passion Iconography in Northern European Art of the late Middle Ages and Early Renaissance. A Study of Transformation of Sacred Metaphor into Descriptive Narrative, Van Ghemmert Publishing Co., Kortrijk.

/// McDonald N., red. 2006. MedievalObscenities, York Medieval Press, Woodbridge.

/// Mellinkoff R. 1993. Outcasts. Signs of Otherness in Northern European Art of the Late Middle Ages, T. I, Berkeley, Los Angeles, Oxford.

/// Mellinkoff R. 2004. Averting Demons. The Protective Power of Medieval Visual Motifs and Themes, Wipf \& Stock Publishers, Los Angeles.

/// Mills R. 2005. Suspended Animation. Pain, Pleasure \& Punishment in Medieval Culture, Reaktion Books, London.

/// Moryń M. 2012. Kocham, nie czytam bzdur!, „Fronda”, nr 64, s. 226-238.

/// Rogers Jr E.F., red. 2001. Theology and Sexuality. Classic and Contemporary Readings, Wiley-Blackwell, Oxford.

/// Salisbury J. 1990. Medieval Sexuality. A Research Guide, Routledge, New York.

/// Steinberg L. 2013. Seksualność Chrystusa. Zapomniany temat sztuki renesansowej, tłum. M. Salwa, oprac. nauk. M. Walczak, Universitas, Kraków.

/// Weir A., Jerman J. 1986. Images of Lust. Sexual Carvings on Medieval Churches, Routledge, London, New York.

/// Wiesner-Hanks M.E. 2000. Christianity and Sexuality in the Early Modern World. Regulating Desire, Reforming Practice, Routledge, London.

/// Wolfthal D. 2010. In and Out of the Martial Bed. Seeing Sex in Renaissance Europe, Yale University Press, New Haven, London. 